\title{
Housing for care: a response to the post-transitional old-age gap?
}

Srna Mandič

This article was originally published in Journal of European Social Policy. 2016. Vol. 26(2) 155-167 by SAGE Publications Ltd. The publishers version of this article is available at http://dx.doi.org/10.1177/0958928716637140.

Suggested citation:

Mandič, Srna. 2016. Housing for care: A response to the post-transitional old-age gap? Journal of European Social Policy 26 (2):155-167. doi: 10.1177/0958928716637140.

\section{ABSTRACT}

This paper examines the trade-off between owned housing and old-age care in Slovenia where the population has been found outstandingly willing to enter residential care and also consume housing wealth for this purpose. To explain this peculiarity, a case study as a holistic in-depth analysis was conducted, combining multiple sources of quantitative survey data and qualitative interview-based insights and accounting for the institutional context and individual decisions. What was found was a modernised version of the traditional 'inheritance for care' exchange, whereby the inheritor partly finances the parent's residential care. This family-mediated trade-off between old-age care and housing wealth was found to serve as an informal equity-release scheme which in Slovenia helps bridge the post-transitional old-age gap, the syndrome of low pensions, underdeveloped care services and owner-occupied housing un-adapted to seniors. Moreover, it is hypothesised that this structural gap is somewhat common to other post-transitional countries.

Housing wealth, home ownership, old-age care, post-socialist countries

\section{Introduction}

As modern societies age, ageing-related issues are being discussed ever more by scholars and policymakers. Interest in older people's welfare is largely driven by concerns for how to ensure that pension, health and long-term care systems remain sustainable in view of the changing ratio between the active and the retired population. In the search for solutions to the growing demands, various additional resources are being considered, including housing assets. Thus, home-ownership is increasingly discussed as equity that can be released and used to improve the financial situation of the elderly and help meet their specific needs (see 
World Bank, 1994; Doling and Ronald, 2010; Doling and Elsinga, 2013); also related to this is the notion of "asset-based welfare" (Ronald, 2006).

Current debates on releasing housing equity in old age are linked to the classical "life-cycle hypothesis of savings" (Ando and Modigliani, 1963). This was a post-war economic theory of what determines saving behaviour over a life-cycle, assuming that people tend to smooth their consumption out over their lifetime. The assumption is that the central age group is characterised by saving, with its wealth tending to peak around the age of 60 to 65 ; the older age group typically engages in lower saving or even dissaving. The life-cycle hypothesis proved useful in econometric modelling, yet empirical evidence showed that "dissaving in old age appears to be at best modest" (Modigliani, 1986: 303). The concern about savings inspiring this theory originated in fears of the precedent economic Great Depression; namely, oversaving was seen as potentially damaging and leading the economy to stagnation. Yet in more recent times the hypothesis was pointed to as part of the opposite concern - how to facilitate dissaving and through new equity release schemes help "avert the old age crisis" (World Bank, 1994).

Ageing brings several challenges and concerns in response to which people may prioritise needs and resources in various welfare domains, especially health, financial security, housing and old-age care. This issue was recently addressed by the 'trade-off' debate, particularly the home-ownership-pension trade-off (see Castles, 1998; Kemeny, 2005; Fahey, 2003, Doling and Ronald, 2010). Established on the macro level, such a link between housing equity and pension systems indicates that countries with high home-ownership rates tend to have less generous public welfare arrangements, including pensions. This relationship implies that 
lower old-age incomes tend to be complemented by financial advantages of home ownership, be it in the form of lower housing costs or via the release of equity through downsizing or moving into rented housing.

The housing equity-pension trade-off has also been discussed and analysed on the micro, household level. More specifically, the DEMHOW project, examining how households in eight European countries perceive housing equity's role in old-age security, revealed that housing wealth is seen as a safety net that people are basically reluctant to consume unless there is an emergency (Doling and Elsinga, 2013). One reason people hold on to their housing assets while spending other assets was the fact that "most older Europeans actually have sufficient income not to have to 'spend' their housing" (Doling and Elsinga, 2013: 141); another was that many see their housing as a substitute for public provision of social and health-care needs; there were also precautionary and bequest motives. However, apart from the general reluctance to spend housing assets which was found to be similar across countries, differences were also found in households' strategies. For example, and of particular note for this paper, Slovenian households were found to be most willing to use their housing equity to finance their residential care costs in excess of their pension (Elsinga and Mandič, 2010). This and other findings posit the impact of the national context in understanding this phenomenon; household strategies within a particular country thus emerged as an important issue yet to be examined, also highlighting the significance of qualitative data (Doling and Elsinga, 2012).

In this paper, we turn to the specific case of the trade-off between home-ownership and oldage care in Slovenia, a country where home-owners are - considerably more than elsewhere 
in Europe - ready to enter residential care and use their housing equity to finance it. Intriguingly, the popularity of residential homes seems to contradict the otherwise significant role of the family in Slovenia, discussed elsewhere (see Mandič, 2010). We wish to shed light on the policy and institutional framework, as well as attitudes and beliefs that underpin this extraordinarily strong inclination to consume housing wealth. The paper therefore aims to examine why this trade-off between housing and old-age care is so significant in Slovenia and help understand how this is maintained on both the macro policy and micro, household levels, combining both quantitative and qualitative, interview-based data. We also wish to consider possible similarities with other post-transitional countries, especially in Central and Eastern Europe, a group that remains quite under-theorised.

For such a purpose, a case study is used as a suitable methodology for a holistic, in-depth investigation (Feagin et al., 1991). More specifically, an exploratory single case study is chosen as an approach (see Yin, 1994) not intended for statistical generalisations, but for a qualitative exploration of the 'how' and 'why' of a phenomenon and to help explain complex causal links in a real-life context; single cases may be used to represent a unique or extreme case; for internal validity reasons, multiple sources of evidence such as surveys, interviews and various documents are suggested, while external validity can be achieved from theoretical relationships.

Accordingly, the paper's structure is as follows. We start by overviewing general debates on old-age care, a significant topic of our analysis. We then start our analysis on the macro level and examine the Slovenian social context, highlighting the relevant institutional and policy arrangements domains of housing and old-age care; these are then combined with survey 
data and cross-country comparisons made to contrast Slovenian specifics with those in other European countries. The next section turns to the micro level; qualitative data obtained from interviews of Slovenian home-owners in the DEMHOW project reveal how home-ownership and old-age care appear linked in personal views. In the conclusion, the findings are discussed and combined to help understand how the Slovenian trade-off between housing and old-age care is maintained, while stressing the significance of the findings for wider debates.

\section{Old-age care - an overview of debates}

Prominent recent debates focus on the issue of providing care to the aged and discuss the welfare state's ability to compensate for the shrinking capacities of traditional familial care. The concept of "new social risks" (Armingeon and Bonoli, 2006; Huber and Stephens, 2006) recognises care for frail old people as one of the new social risks; unlike traditional social risks, these risks have yet to be properly responded to by the welfare state after traditional family structures and the work-family balance started to change with the mass employment of women. In contrast to 'old social risks' which are generally covered by money transfers, the new social risks require services, particularly care for the frail, a task of the "postindustrial welfare state" (Huber and Stephens, 2006). Examining public expenditure on the 'old' and 'new social risks' across groups of European countries, Armingeon and Bonoli (2006) found that Nordic countries reacted to these new social risks a lot earlier than others, whereas among new member states in particular the response has been delayed. 
Much discussion about providing care for the elderly is based on the welfare regimes typology, introduced by Esping-Andersen. After addressing welfare regimes in terms of "how provision of welfare is allocated between the state, market and family" (Esping-Andersen, 1999: 73), the process of "defamilialisation" of services came to the fore of his discussion. Examining the level to which household services, especially child and elderly care, have been "defamilialised" - i.e. externalised from the family, he paid particular attention to the "familialistic" Southern European countries where familial care for frail members is still the norm and an obstacle to women's employment, while the welfare state's role in these services is only marginal. Generally, welfare regimes were shown to vary widely concerning the level of defamilialisation of household services. Notably, the share of seniors receiving home-based services - a significant indicator of defamilialisation - was found to vary from $19.5 \%$ in social-democratic regime, $4.5 \%$ in liberal and continental regimes to as low as $1.3 \%$ in the Southern European regime (Esping-Andersen, 1999: 61). The bias between the 'service-rich' Nordic group and the 'service-poor' Southern European group, where professional support for older people is scarce, was confirmed several times (see Sarasa and Bilingsley, 2008; Brandt et al., 2009). Yet much less has been found for transitional countries. According to Saraceno (2010), one of the rare studies, in Eastern European countries the coverage of care services for older people is generally low, with families continuing to be the key care provider.

Of particular note is the debate inspired by the 'crowding out hypothesis' which argues that strong welfare state engagement can undermine intergenerational family solidarity. Yet empirical testing of SHARE data did not confirm that the care service would 'crowd out' children's care for parents and lead to reduced contacts among them (Sarasa and Bilingsley, 
2008). Further, Esping-Andersen (2009) argues that the well-being of families depends on the defamilialisation of care services like universal day-care; kinship bonds might be weakened by an excessive caring burden so professional services are needed to make familial care obligations manageable. Finally, it was shown that, depending on the availability of services, professional care providers tend to take over demanding, regular physical care, while the family is inclined to more sporadic, easier help (Brandt et al., 2009).

When discussing old-age care and support as an element of the intergenerational flow of resources, and thus the possible trade-offs, the parent-owned home was stressed as specifically relevant in two ways. First, it represents accumulated wealth that can later be bequeathed to kin (Szydlik, 2004); this form complements inter-vivos transfers (Albertini and Radl, 2012) and is a possible basis for a "care-for-inheritance generational contract" (Poggio, 2008). The second is the co-residence of parents and adult children. While marginal in other regions, such co-residence is found common in Southern Europe where it allows parents to obtain support and care from their adult children, but also lets parents support younger generations with accommodation and childcare (lacovou, 2004; Albertini and Kohli, 2013). For Esping-Andersen (1999), the co-habitation of parents and adult children is a significant indicator of 'familialism'. However, in a cross-national analysis of older people's living arrangements, one of the few studies to also cover transitional countries, some of them were found to even surpass the South European; most notably, lacovou and Skew (2011: 471) reported that the Slovenian older population is characterised by a comparatively very high proportion of co-residing with adult children, which among older couples is the highest figure in the EU. 


\section{The social context}

We now turn to an overview of the Slovenian institutional frameworks, policy arrangements and circumstances in housing and old-age care. This is the macro context that affects decisions made on the micro, household level. However, while contextualisation is needed to understand individual behaviour and particularly for its cross-country comparisons, the links between the diverse levels are not direct but also mediated through culture.

Slovenia became an independent state in 1991, in 2004 it was one of the earliest transitional countries to join the EU, while in 2010 it became a member of the OECD. The socialist system's legacy included the full employment of women, well-developed health care and a comprehensive social and protection system. The welfare system and its benefits were financed by obligatory contributions by employers, while the provision of services was dominated by a highly decentralised public sector (Kolarič et al., 2009). The economic conditions were also quite favourable and the system of self-management left the country with relatively open market arrangements and a relatively good level of economic development. Overall and unlike in most other transitional countries, the social protection system managed comparatively well to endure the transitional shock, maintain the vital income of the population facing new transition-related risks and keep one of the lowest riskof-poverty rates in the EU (Stanovnik and Čok, 2009; Filipovič et al., 2013). As part of dealing with the transitional shock and to keep the unemployment rate down, the Slovenian pension system has been characterised by early retirement, a low pension-to-wage ratio and an unsustainable burden on the state budget (EC, 2007; Stanovnik and Čok, 2009) The pension reform in 2012 took some steps to alleviate these problems. The public contribution-based 
pension insurance system is paramount, while other voluntary private schemes only play a supplementary, more marginal role.

Slovenia is one of the countries where ageing-related pressures on public spending are strongly pronounced, with projections for 2030 showing that public expenditure on pensions, health care and long-term care is expected to significantly exceed the European average (EC, 2007: 112, 134). Focused on transitional changes, there have only been slight policy responses to demographic ageing in the last decades.

As a new member state, Slovenia is usually classified in the welfare system of transition countries (Manning, 2004; Offe and Fuchs, 2007). However, two welfare regime characteristics were pointed out as relevant for Slovenia (Kolarič et al., 2009). The first is the principle of contribution-based benefits, the key trait of the conservative-corporatist welfare regime, that is strongly present in Slovenian pension and health care insurance. The second is the subsidiarity principle which allocates responsibility for individual well-being between the family, civil organisations and the state, with the higher level only becoming responsible when lower levels fail. With strong Catholic roots, this principle endured the socialist period and has been increasingly applied by post-transitional reforms. However, these two principles are mediated through specific institutional frameworks whose main features are described below. 


\section{Housing}

Concerning housing provision, Slovenia has traditionally supported owner occupation. In 1990, prior to transition, the home ownership rate was $66 \%$. The fast and drastic privatisation made the home-ownership rate rise to $90 \%$ in 1992 (see Cirman, 2006). Slovenia thus became one of the CEE countries with high home ownership rate and a miniature rented sector (Mandič, 2010). The state drastically withdrew from housing, with its housing expenditure representing one of the smallest proportions of GDP in the EU-27. The practice of self-help housing construction and of 'in place adjustments' still continued after being widespread under socialism and sustaining the feeling of belonging to the local community (Filipovič Hrast, 2008). Together with the weakly regulated real estate market, the widespread and dispersed real estate property ownership by households (in the form of second homes, unoccupied housing, land) and the continuous growth in housing prices up to late 2008, these factors have led to housing becoming one of the best ways to invest personal savings. Hence for significant numbers of households housing assets comprise a very important element of present and future material security. The role of the family has also been found to be very important, being vital for housing younger generations (Cirman, 2006; Mandič 2008).

- $\quad$ Table 1 here -

In this context, specific housing outcomes of the older population can be highlighted. According to the SHARE data in Table 1, the Slovenian population over 50 years of age is characterised by quite distinctive features compared to average figures for EU and CEE 
countries. Senior Slovenians are more often homeowners, reside in single-family housing and co-reside with an adult child; for a very long time they have been staying in the present residence, which is very rarely adapted to the needs of the elderly. In addition, compared to the EU their housing stock is fairly well modernised, but with relatively low space standards (see Filipovič Hrast et al., 2013). Supported housing is too rare to be detected by the SHARE sample. Regarding its potential for a trade-off for old-age care, the quality of senior Slovenians' housing may be summarised as quite modernised, less spacious and insignificantly adapted to the needs of the elderly; it is frequently shared with an adult child and predominately in the form of single-family housing, with paramount home-ownership.

\section{Old-age provisions and long-term care}

The Slovenian system of old age care under socialism was characterised by a relatively welldeveloped network of public homes for the elderly, often also providing minor home-based services. After the transition, old-age provision entered the policy agenda relatively late when in 2006 the long waiting lists for institutional homes, their shortage and lack of modernisation became a concern, soon followed by the emergence of private homes with concessions, mostly granted to the Roman Catholic Church as a provider. Policy priorities (MDDSZ, 2006) were also set for more individualised treatment and the introduction of new support services and their integration. For people over 65 years, goals of $5 \%$ coverage in institutional care and old-age homes and of 3\% coverage in home-based support services were set. The goals of institutional coverage and its pluralisation have been met, but modern comfort and nursing capacities remain an issue. Informal family care for the aged is still significant (Kolarič et al., 2009). However, home-based services are only slowly developing, with their accessibility and affordability varying strongly between municipalities (Hlebec et 
al., 2014). The integration of diverse services and providers and insurance for long-term care are still required and in preparation.

To cover old-age care costs, the individual's contribution to services looms large in Slovenia. Old people's homes and supported housing are paid by users and their relatives if possible; if not, the municipality, being the responsible subsidiary, provides supplementary finances for the cost of the care; however, the municipality obtains a mortgage over the person's housing equity, if any, and is repaid after their death.

Compared to other countries, the Slovenian system of care for the elderly involves a strong emphasis on informal (kinship-network-based) care and institutional care, while intermediary home-based support services are less significant (Elsinga and Mandič, 2010). This is in line with findings of Saraceno (2010: 36), based on older figures, that with its $4 \%$ coverage of institutional care Slovenia is ranked in the middle, while with its $2 \%$ coverage of home-based services it appears in the bottom third of European countries.

General opinions and popular attitudes concerning ageing-related issues reported by Eurobarometer 2007 (Table 2) mirror the discussed policy and institutional features of oldage care.

Table 2 here

The vast majority of the Slovenian population expects to pay for their long-term care by themselves, and very few expect public authorities to step in; this attitude is much more 
pronounced than in average CEE and EU figures. Another distinguishing feature is the preference for a nursing home as the best option for fragile elderly, in Slovenia it is the leading option of all options, and clearly more popular than elsewhere. Further, one in two Slovenians agree that if a dependent elderly person cannot pay for their care, their housing asset should be used to pay for it; again, in Slovenia this inclination is declared much more than elsewhere. In sum, concerning the readiness to rely on one's personal means, including housing assets, to pay for the cost of old-age care, Slovenia diverges from the EU in the same direction as other CEE countries, yet much further. The same applies to the popularity of nursing homes.

\section{Personal views on links between old-age care and owned housing}

In this section, we look at personal views which show how old-age care and owned homes are connected on the micro level, in people's perceptions. We wish to observe the subjective meanings home-owners attach to their housing asset regarding their need for care in old age. First, by means of a hypothetical case of an old lady becoming unable to care for herself, a discussion of the need for old-age care was initiated where respondents' revealed their general perceptions of the responsibilities and related resources. When analysing these perceptions and people's discussions of their expectations of their own old age, we focus on how housing is addressed. We aim to identify the links respondents spontaneously established between care and housing. We also wish to pinpoint the issues that respondents raised as significant because they can reveal the norms underlying the choice between various options. Finally, we analyse people's attitudes articulated in response to a question about the significance of their housing in their retirement. 
We present the views expressed in interviews of 30 Slovenian homeowners as part of the project Demographic Change and Housing, DEMHOW; the project aimed to investigate how demographic change and housing wealth are linked in eight EU countries (Doling and Elsinga, 2013). The interviews were structured around a questionnaire developed by research partners from all countries, and included vignettes as a way to organise the discussion. Slovenian interviews were carried out in Celje in June and July 2009 in people's homes. Ten interviews were made in each age cohort: the young, 25 to 35 years; the middle cohort, 45 to 55 years, and the older cohort, 65 to 75 years. Each group included respondents to cover diverse types of housing and of households in terms of demography and stratification.

\section{Old age care: responsibility and expectations}

The issue of old-age care was introduced to respondents by presenting a vignette depicting an old lady living alone, becoming frail and no longer able to care for herself, while her two children were living in another town. When invited to address the old lady's possible options, the respondents' common initial reaction was to turn to her children and consider moving in together, with either the child or the lady joining the other. Often, after this initial option was reflected on and found unrealistic, two more options were arrived at - a home for the elderly and the status quo with additional support at home. Co-residence generally figured as a starting point for consideration, a norm, which often turned out impracticable after thorough reflection. While a few younger respondents settled on co-residence as a final choice, no such choice was detected among the oldest respondents. They were clearly oriented to either a home for the elderly or to prolonging their stay at home for as long as 
possible while receiving additional support; there was also a clear concern that the old lady should not become a burden on her children and spoil their relationship.

Well, look, she could theoretically go stay with the children, but I would not advise her to do so. Because ... such an old lady is a big burden for this young family which is already heavily overburdened, you know. Now, if this lady was still in such a condition that she could provide help to the family, that would be fine, but so ... to force something ... I think then conflicts would come and in that case a home for the elderly is better (65-75 years, woman, with children).

It is noteworthy that other options, in particular supported housing and moving closer to either child, were scarcely mentioned.

The next question concerned who should be responsible for caring for the old lady. Here, the responsibility of her children featured prominently. Respondents often tried to specify the point beyond which professional care is needed (such as injuries) and to define the children's responsibility for arranging and (co)financing it. In explanation of why the children are the first responsible, three arguments appeared. According to the first and paramount one, the children's responsibility for their parents was taken for granted and part of mutual obligations between the closest kin; the second explanation referred to legal obligations; while the third was an exchange in the sense that children are responsible for old-age care in exchange for inheritance in the form of housing and money. "It is who gains and inherits ... he must provide care..." (45-55 years, women, no children). 
Another issue very often raised by respondents was the process of deciding how to help the old lady. The respondents repeatedly stated that various options, including sharing the cost of home-based or institutional care should be discussed by actors in the vignette and then collectively decided on.

I: Who should be responsible for her care?

R: Well, by all means this is a matter of agreement ... for the children and all ... they should sit down around a table, discuss this, see what they can... and what would suit her to.... Everything together, all sides should be considered ...

I. Why so?

R: Well, such a moment comes in your life ... this must be discussed, what to do, a wise solution found, that is good for all, also for this old woman ... as well as for her children. We know how it is for them nowadays ... they work all day long ... it is not easy.... But these things should be discussed earlier... We discuss this at home ... and when it gets thus far, both our mothers would probably decide on the home ... they can see that we do not have the time.... We are away from home practically all day (45-55 years, woman, with children).

Generally, coming to a decision and deliberation were frequently implied in the answers; sometimes in the form of multiple options that need to be ranked by the actors in the vignette; some even spelled it out as very important collective decision-making leading to a solution that is best for and accepted by all.

Respondents were later openly asked about their own expectations of who would take care of them if needed in old age. Most responses were polarised between the option of children 
and a home for the elderly. In many cases, the help of children was expected as long as the respondent could live independently, but afterwards the option was a home for the elderly.

Well, I think that first of all my partner would take care of me; and if there is no partner, then I think the children would come to help because also we would comfort our parents ... and if help is needed we would have some kind of agreement so somebody is always there to help; so I think also the children would be there for me.... Unless there is a serious disease and one is tied down to bed or so ... in that case ... there is not so much to think what to do, I would decide on some sort of home for the elderly (25-35 years, man, no children).

This was basically the general pattern; however, the oldest group with children chose the home for the elderly more frequently and more easily than others.

The question about the cost of the care was raised separately later. Most respondents revealed they expect to be able to cover the cost of their old-age care by themselves from their pensions and with the assistance of their children.

Who would cover such costs - myself, and I hope that would be enough; most likely also the children would add something; perhaps also the municipality (woman, 45-55, with children).

Frequently, in addition to one's own pension and help from the children the home was mentioned as an asset that can be used to finance the home for the elderly. 
There is my pension and if this is not enough, perhaps my daughters would contribute, otherwise I will have to sell my house (woman, 45-55 years, with children).

Only a few respondents mentioned other sources such as private insurance. Most respondents were quite confident that the cost of their care in old age should not be a problem and that it would be managed through a combination of their pensions, financial assistance from children or by selling their home and that this would suffice. The role of authorities was clearly seen as subsidiary - only in case the family could not do it.

\section{The home as a tradable resource?}

Unlike before when the housing asset appeared in the discussion spontaneously, in this section the role of housing equity was questioned explicitly. Respondents were first asked to estimate their housing equity in terms of its present assumed market value and to compare it with its initial value when acquired. Without exception, all respondents estimated that the value of their property had risen. Despite the falling real-estate prices in the last few years, all respondents seemed to share the experience that housing equity was a good investment.

Respondents were also first asked whether they see any financial significance of their home in retirement. Some acknowledged a negative impact - the financial burden of costly heating and repairs. Also expressed was a general feeling of the security provided by their property and home as a safe place from which one cannot be evicted. The dominant impression was about a positive financial role in the sense the home could be sold if necessary, thus acknowledging the equity; some respondents specified it precisely for the case of any entry 
to a home for the elderly, when it could sold and the proceeds used to cover the cost in excess of their pension. In some cases, these considerations were also related to the option of leaving an inheritance and the possible role of the children.

Why would it be significant? Well, if I happened to want to go into a home for the elderly, I would probably need to pay more than my pension would cover so I might make a deal with somebody for such an additional payment, otherwise I would need to sell my home. So my home is some kind of security, it is an asset which can cover additional payment for an elderly home, if I were to accept this; I don't know now if I would accept this... (woman, 45-55 years, without children).

The financial significance of their home was also reported by way of selling and moving into smaller unit, or renting out part of the house. However, the option of moving into a rented dwelling was not recognised at all, which is quite realistic for Slovenia.

\section{Conclusions}

This paper set out to examine the trade-off between owned housing and old-age care in Slovenia where the population has already been found to be outstandingly willing to enter residential care and consume their housing wealth for this purpose. More interestingly, this inclination seems to contradict the otherwise strong Slovenian familialistic orientation evident in the high rate of cohabitation between parents and adult children. The aim of analysis was to shed light on this specificity of Slovenia and help understand how this tradeoff is maintained on the macro and micro levels, thus accounting for both the policy and institutional context and subjective individual views and choices. 
The examined comparative quantitative data showed how this orientation is well in tune with policy and institutional arrangements. In contrast to the scarce home-based services for the elderly, residential homes are relatively available; the cost is traditionally covered by a resident's pension and, if insufficient, the institutionalised subsidiarity principle passes the obligation on to adult children; in the case of the children's inability to pay, the obligation is subsidiarily passed on to the municipality which, in turn, is given a mortgage over the person's housing asset until the liability is repaid by inheritors. The comparative data on the housing stock of senior Slovenians shows that supported housing and specific housing schemes for the elderly are extremely rare; owner-occupied homes are well modernised, yet unadjusted to the specific needs of the elderly; moreover, homes are very often shared with an adult child. Therefore, generally speaking, seniors' housing assets are significant yet unadapted to their specific needs and, since they are frequently shared with adult children, this also represents a 'family issue'.

Displaying common perceptions of old-age care, the interviews revealed how various questions of old-age care are also considered a family issue. The dominant pattern for financing old-age care that emerged combines the pension, the help of children and, if needed for residential care, the housing equity. The role of adult children is particularly important, looming large at the turning point where a frail parent is no longer able to live independently; adult children were given the major role in consideration of the responsibilities and resources available for resolving such a situation. They were seen as most responsible for organising the support or a residential home, and also for helping to pay for it. This seems to reflect the underlying traditional, pre-modern norm whereby an heir inherited the farmhouse and in exchange became responsible for the lifelong provision for ancestors. This traditional 'exchange formula' seems to be still latent, yet functioning in a 
modernised and partly monetarised version - in return for inheritance or possession of the home, inheritors partly pay for their ancestor's care; if they do not do so, the municipality steps into this very pattern.

In explaining the relative popularity of residential homes in Slovenia, the widespread role of the co-residence of elderly parents and adult children also seems critical. As a prominent indicator of familialism, co-residence can be expected to inhibit the choice of an institutional residential home as an old-age care option. Our interviews showed that this is so, but only up to the point where parents need more support for independent living. This seems to be the point at which the filial help of co-residing children becomes unbearable. However, as depicted by the respondents recognition of this point is often subject to wider family deliberation and negotiation; in these procedures, the norms along with the institutionally generated opportunities and circumstances are considered and filtered before final choices are made. Social circumstances are significant in the configuration of this turning point, identified on the macro scale - the underdeveloped professional home-based services and unadjusted housing to the needs of elderly owners. These circumstances are not favourable for frail elderly people to stay at home.

The family has clearly proven to be a significant agent. It is often the medium in which not only issues are discussed and decisions made, but also one which has to be sustained and good relations kept as a priority. In this sense, our interviews give additional evidence against the 'crowding out' hypothesis; the respondents often perceived residential care services as a means by which to avoid too heavy a caring load and to keep intergenerational relationships unspoiled. The family was also shown as the body in which the trade-off between old-age care and home-ownership can be carried out, partly also in monetarised 
form. The intergenerational flow of resources, where adult children cover the cost of residential care in excess of the parents' pension and in exchange for the housing asset, thus represents a specific case of an informal equity-release scheme. To some extent, this also supports the Modigliani-Brumberg "life-cycle hypothesis" and shows yet another practice of how seniors consume some of their housing wealth, however not as isolated individuals but as part of a multi-generational family network coming to an agreement.

Finally, our case study showed how in Slovenia the family helps bridge the post-transitional old-age gap, the syndrome of low pensions, underdeveloped care services and owneroccupied housing unadapted to seniors' needs. While analysed as specific, the Slovenian case might perhaps share some structural similarities with other CEE countries, a group that remains quite under-theorised. Besides the already recognised common post-transitional legacies, such as a highly privatised housing stock and delays in modernising old-age care, our comparative data provided further indicators of the common structural old-age gap; namely in popular views on old-age care options CEE countries diverge from the European average to a smaller degree than Slovenia, yet consistently in the same direction. Accordingly, it can only be hypothesised that the structural old-age gap, the syndrome of unmodernised old-age care services, low pensions and owner-occupied housing unadjusted to the needs of seniors are a shared feature and common future challenge of posttransitional countries.

Funding

This work was supported by the Agency for research and development of the Republic of Slovenia, grant number 0582 P5-0200-6312-3/2010-443]. 


\section{References}

Albertini, M. and Kohli, M. (2013) 'The generational contract in the family: An analysis of transfer regimes in Europe', European sociological review 29: 828-840.

Albertinl, M. and Radl, J. (2012) 'Intergenerational transfers and social class: Inter-vivos transfers as means of status reproduction?', Acta Sociologica 55: 107-123.

Ando, A. and Modigliani, F. (1963) 'The Life Cycle Hypothesis of Saving: Aggregate Implications and Tests', The American Economic Review 53: 55-84.

Armingeon, K. and Bonoli, G. (Eds.) (2006) The Politics of Post-Industrial Welfare States. London in New York: Routledge.

Brandt, M., Haberkern, K. and Szydlik, M. (2009) 'Intergenerational help and care in Europe', European Sociological Review 25: 585-601.

Castles, F. (1998) 'The really big trade-off: home ownership and the welfare state in the New world and the Old', Acta Politica 33: 5-19.

Cirman, A. (2006) 'Housing tenure preferences in the post-privatization period: the case of Slovenia', Housing Studies 21: 113-134.

Doling, J. and Elsinga, M. (2012) 'Housing as Income in Old Age', International journal of housing policy 12: 13-26.

Doling, J. and Elsinga, M. (Eds.) (2013) Demographic Change and Housing Wealth: Homeowners, Pensions and Asset-Based Welfare in Europe. Dordrecht, Heidelberg, New York, London: Springer. 
Doling, J. and Ronald, R. (2010) 'Property-based welfare and European homeowners: how would housing perform as a pension?', Journal of Housing and the Built Environment 25: $227-241$.

Elsinga, M. and Mandič, S. (2010) 'Housing as a piece in the old age puzzle', Teorija in praksa 47: 940-958.

Esping-Andersen, G. (1999) Social Foundations of Postindustrial Economies. Oxford: University Press.

Esping-Andersen, G. (2009) The Incomplete Revolution. Cambridge: Polity Press.

European Commission (2007) Europe's demographic future: Facts and Figures on Challenges and Opportunities, available on: http://ec.europa.eu/employment_social/spsi/ docs/social_situation/demo_report_2007_en.pdf (accessed 18 November 2008).

Fahey, T. (2003) 'Is there a trade-off between pensions and home-ownership', Journal of European Social Policy 13: 159-173.

Feagin, J., Orum, A. and Sjoberg, G. (eds) (1991) A case for case study. Chapel Hill, NC: University of North Carolina Press.

Filipovič Hrast, M. (2008) 'Influences on the sense of neighborhood: case of Slovenia', Urban affairs review 43: 718-732.

Filipovič Hrast, M., Kopač Mrak, A. and Rakar, T. (2013) 'Social exclusion of elderly in Central and Eastern Europe', International Journal of Social Economics 40: 971-989.

Hlebec, V., Mali, J. and Filipovič Hrast, M. (2014) 'Community care for older people in Slovenia', Anthropological notebooks, in print.

Huber, E. and Stephens, J. (2006) 'Combating Old and New Social Risks', in K. Armingeon and G. Bonoli (eds) The Politics of Postindustrial Welfare States, pp. 143-168. London: Routledge. 
lacovou, M. (2004) 'Patterns of family living', in R. Berthoud and M. lacovou (eds)

, Social Europe: Living Standards and Welfare States, pp. 21-45. Cheltenham: Edward Elgar.

lacovou, M. and Skew A. (2011) 'Household composition across the new Europe: Where do the new Member States fit in?', Demographic Research 25: 465-490.

Kemeny, J. (2005) 'The Really Big Trade-Off between Home Ownership and Welfare: Castles' Evaluation of the 1980 Thesis, and a Reformulation 25 Years on', Housing, Theory and Society 22: 59-75.

Kolarič, Z., Kopač Mrak, A. and Rakar, T. (2009) 'The Slovene welfare system: gradual reform instead of shock treatment', in K. Schubert, S. Hegelich and U. Bazant (eds) The handbook of European welfare systems, pp. 444-461. London, New York: Routledge.

Mandič, S. (2008) 'Home-Leaving and its Structural Determinants in Western and Eastern Europe: An Exploratory Study', Housing Studies 23: 615-637.

Mandič, S. (2010) 'The Changing Role of Housing Assets in Post-Socialist countries', Journal of Housing and the Built Environment 25: 213-226.

Manning, N. (2004) 'Diversity and change in pre-accession Central and Eastern Europe since 1989', Journal of European Social Policy 14: 211-232.

MDDSZ (2006) Strategija varstva sterjših do leta 2010 - Solidarnost, sožitje in kakovostno staranje prebivalstva. Ljubljana: MDDSZ, available on: http://www.mddsz.gov.si/ fileadmin/mddsz.gov.si/page uploads/dokumenti_pdf/strategija-SI-starejsi.pdf (10 January 2014).

Modigliani, F. (1986) 'Life Cycle, Individual Thrift, and the Wealth of Nations', The American Economic Review 76: 297-313. 
Offe, C. and Fuchs, S. (2007) Welfare State Formation in the Enlarged European UnionPatterns of Reform in the Post-Communist New Member States, Discussion Paper SP IV 2007-306, Wissenschaftszentrum Berlin fur Socialforschung 2007.

Poggio, T. (2008) 'The intergenerational transmission of home ownership and the reproduction of the familialistic welfare regime', in C. Saraceno (ed) Families, Ageing and Social Policy, pp. 59-87. Cheltenham: Edward Elgar.

Ronald, R. (2006) Convergence? Home Ownership and Asset-Based Welfare Regimes, Delft: International Workshop Home Ownership in Europe: policy and research issues.

Saraceno, C. (2010) 'Social Inequalities in facing old-age dependency: a bi-generational perspective', Journal of European Social Policy 20: 32-44.

Sarasa, S. and Billingsley, S. (2008) 'Personal and household caregiving from adult children to parents and social stratification', in C. Saraceno (ed) Families, Ageing and Social Policy, pp. 123-146. Cheltenham: Edward Elgar.

Stanovnik, T. and Čok, M. (2009) 'The Transition process and Changes in Income, Income Inequality and Poverty: The Case of Slovenia', in M. S. Stanculescu and T. Stanovnik (eds) Activity, Incomes and Social Welfare, pp. 231-268. Farnham: Ashgate.

Szydlik, M. (2004) 'Inheritance and inequality: Theoretical reasoning and empirical evidence', European Sociological Review 20: 31-45.

World Bank (1994) Averting the Old Age Crisis: Policies to Protect the Old and Promote Growth. Washington DC: World Bank.

Yin, R. (1994) Case study research: Design and methods (2nd Ed.). Thousand Oaks, CA: Sage Publishing. 
Table 1: Housing characteristics of population $50+$

$\begin{array}{lll}\text { Slovenia } & \text { CEE }^{*} \quad U^{* *}\end{array}$

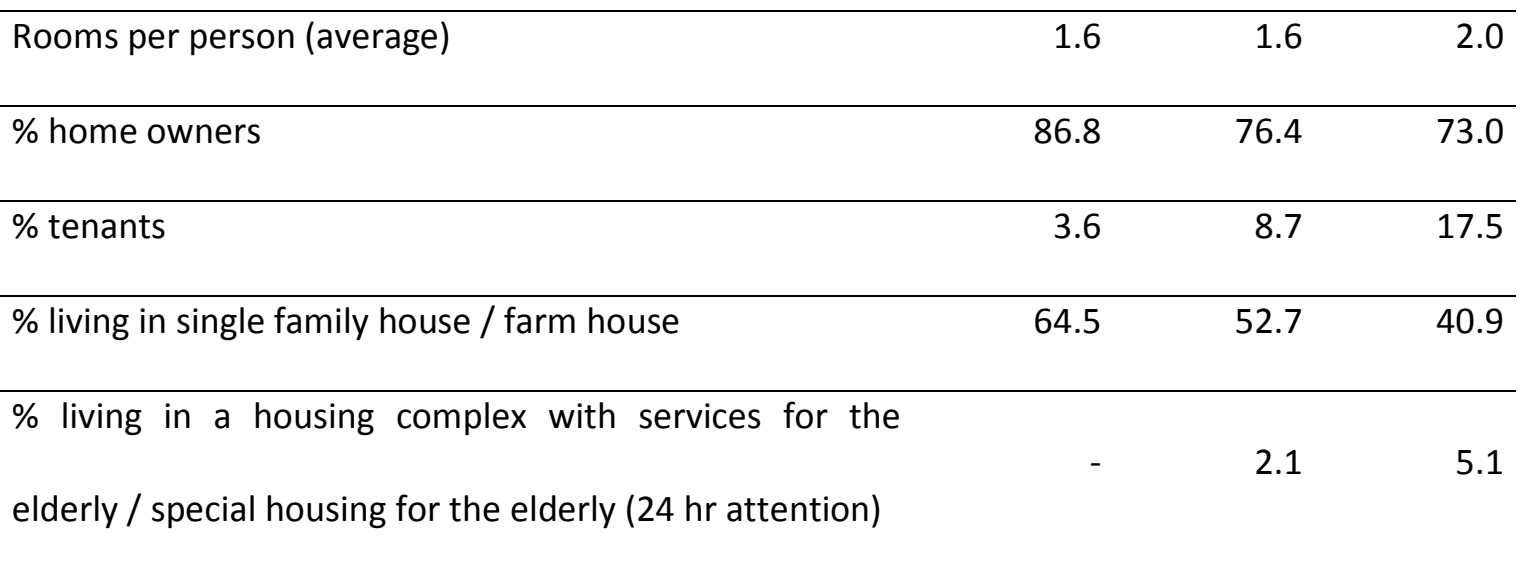

$\%$ with accommodation adaptations for people with

$\begin{array}{lll}2.5 & 4.3 & 6.5\end{array}$

physical impairments or health problems

\begin{tabular}{|c|c|c|c|}
\hline No. of years in present accommodation (median) & 32.0 & 30.3 & 23.8 \\
\hline$\%$ co-residence with adult child & 57.7 & 48.3 & 38.1 \\
\hline Household size (no. of persons - average) & 2.4 & 2.5 & 2.3 \\
\hline
\end{tabular}

Source: SHARE 2013, own calculations

*CEE (Central and Eastern European) countries include the following: Czech, Hungary, Poland and Slovenia;

** EU includes the following 16 countries covered by SHARE: Sweden, Denmark, Netherlands, Austria, Belgium, France, Germany, Greece, Italy, Portugal, Spain, Czech Republic, Estonia, Hungary, Poland, Slovenia. 
Table 2: Opinions for old-age care

Slovenia CEE* EU-27

\begin{tabular}{llll}
\hline \% expecting to pay for their long-term care themselves & 72 & 56 & 48
\end{tabular}

\begin{tabular}{llll}
\hline$\%$ expecting public authorities to pay for their long-term care & 17 & 23 & 32
\end{tabular}

$\%$ considering a nursing home the best option for fragile elderly

$32 \quad 15 \quad 10$

$\%$ agreeing that if a person becomes dependent and cannot pay for care

from their own income, their flat or house should be sold or borrowed

$52 \quad 30 \quad 25$

against to pay for care

Source:

Eurobarometer, Health and long-term care in the European Union, no. 283, Dec 2007

http://ec.europa.eu/public opinion/archives/ebs/ebs 283 en.pdf 